\title{
ANALISIS EFEKTIVITAS PENERIMAAN PAJAK KENDARAAN BERMOTOR DAN BEA BALIK NAMA KENDARAAN BERMOTOR TERHADAP PENDAPATAN ASLI DAERAH SEBELUM DAN SESUDAH BERLAKUNYA SURAT KEPUTUSAN GUBERNUR JAWA BARAT NOMOR 973 /154 2018
}

\author{
Thomas Nadeak \\ Fakultas Ekonomi dan Bisnis UBP Karawang \\ Misterichi@yahoo.com \\ Eva Sunasti \\ Fakultas Ekonomi dan Bisnis UBP Karawang \\ ABSTRACT
}

\begin{abstract}
This study aims to find out how much motor vehicle tax receipts and motor vehicle transfer fees in Samsat Karawang regency with the existence of governor's decree number 973/147 regarding the granting of principal exemptions and administrative sanctions in the form of fine fees for transfer of name of motorized vehicles $(\mathrm{BBNKB})$ on the transfer of ownership second and in the form of a motor vehicle tax penalty $(\mathrm{PKB})$ the type of research investigated by researchers is in the form of case studies. The data obtained by researchers is data taken directly from the Karawang district samsat office. the data received is secondary data, in the form of annual acquisition data from motor vehicle tax receipts and transfer fees for 5 years namely 2014 to 2018 from the study concluded that motor vehicle tax revenue was well realized and reached the target each year, in the year 2018 motor vehicle tax revenue reaches its target of $105.99 \%$ with this it can be stated that the effectiveness of revenue is very good while in the transfer fees of motorized vehicles in 2018 experienced revenues of 112.90 of the target set, this means that effectiveness in 2018 has reached the specified target.
\end{abstract}

Keywords: Effectiveness of Motor Vehicle Tax Revenue, Motor Vehicle Title Transfer Fees and Original Revenue of Karawang Regency 


\begin{abstract}
ABSTRAK
Penelitian ini bertujuan untuk mengetahui seberapa besar penerimaan pajak kendaraan bermotor dan bea balik nama kendaraan bermotor di Samsat Kabupaten Karawang dengan adanya surat keputusan gubernur nomor 973/147 tentang pemberian pembebasan pokok dan sanksi administratif berupa denda bea balik nama kendaraan bermotor (BBNKB) atas penyerahan kepemilikan kedua dan berupa denda pajak kendaraan bermotor (PKB) jenis penelitian yang diteliti peneliti berupa studi kasus. Data yang didapatkan oleh peneliti adalah data yang diambil langsung dari kantor samsat kabupaten karawang. data yang diterima adalah data sekunder, berupa data perolehan tahunan dari penerimaan pajak kendaraan bermotor dan bea balik nama selama 5 tahun yakni tahun 2014 sampai dengan 2018 dari penelitian tersebut mendapatkan penyimpulan bahwasannya penerimaan pajak kendaraan bermotor terealisasi dengan baik dan mencapai target setiap tahunnya, pada tahun 2018 penerimaan pajak kendaraan bermotor mencapai targetnya sebesar 105,99\% dengan ini dapat dinyatakan bahwa efektivitas pada penerimaan sangat baik sedangkan pada bea balik nama kendaraan bermotor pada tahun 2018 mengalami penerimaan sebesar 112,90 dari target yg ditentukan, dengan ini berarti efektivittas pada tahun 2018 telah mencapai target yang telah ditentukan.
\end{abstract}

Kata Kunci : Efektivitas Penerimaan Pajak Kendaraan Bermotor,Bea Balik Nama Kendaraan Bermotor dan Pendapatan Asli Daerah Kabupaten Karawang.

\title{
Latar Belakang
}

Dalam rangka meningkatkan pendapatan daerah, Pemerintahan Daerah menjalankan fungsi dan kewenangan dalam bentuk peraturan sebagai pengendalian efesiensi dan efektivitas pendapatan untuk daerah dalam menjalankan fungsi dan kewenangannya Pemerintahan Daerah berkerja sama dengan SAMSAT untuk melakukan pemungutan pajak kendaraan bermotor, dimana sebagian besar penduduk di daerah menggunakan kendaraan bermotor.

Pajak Daerah adalah kontribusi yang wajib kepada daerah yang terutang oleh orang pribadi atau badan yang bersifat memaksa berdasarkan pada undang-undang 
dengan tidak mendapatkan imbalan secara langsung dan digunakan untuk keperluan daerah bagi sebesar-besarnya kemakmuran rakyat ${ }^{1}$.

Pajak kendaraan bermotor termasuk pada jenis pajak provinsi yang merupakan bagian dari Iuran Pajak Daerah. Pada Undang-Undang nomor 28 tahun 2009 pada pasal 1 angka 12 dan 13 yang menyatakan pajak atas kepemilikian kendaraan bermotor. Objek pajak kendaraan bermotor kepemilikan dan/ atau penguasa kendaraan bermotor. Termasuk dalam pengertian Kendaraan Bermotor adalah kendaraan bermotor beroda beserta gandengannya yang dioperasikan di semua jenis jalan darat dan kendaraan yang dioperasikan di air dengan ukuran isi kantor GT 5 (lima Gross Tonnage) sampai dengan GT 7 (tujuh Gross Tonnage). Dikecualikan dari pengertian Kendaraan Bermotor yaitu, Kereta Api, kendaraan Bermotor yang semata-mata digunakan untuk keperluan pertahanan dan keamanan negara, Objek pajak lainnya yang ditetapkan dalam Peraturan Daerah $^{2}$.

\footnotetext{
${ }^{1}$ Undang-Undang nomer 28 tahun 2009 pasal 1 angka 12, Pajak Daerah dan Retribusi Daerah
}

${ }^{2}$ Abdul Halim, Perpajakan edisi 2 (Jakarta Selatan: Salemba Empat 2016), hlm.503 
Tarif pajak untuk setiap jenis pajak adalah $1 \%$ dan yang paling tinggi yaitu $2 \%$ untuk kepemilikan kendaraan bermotor pertama yaitu dimana kepemilikan kendaraan bermotor tersebut baru memiliki kendaraan bermotor petama kalinya, untuk kepemilikan kendaraan bermotor kedua dan seterusnya tarif dapat ditetapkan secara progresif paling rendah sebesar $2 \%$ dan paling tinggi sebesar 10\%, sedangkan utuk tarif Bea Balik Nama Kendaraan Bermotor ditetapkan paling tinggi sebesar $20 \%$ untuk penyerahan pertama dan $1 \%$ untuk penyerahan kedua dan seterusnya ${ }^{3}$.

Bea Balik Nama Kendaraan Bermotor pada Undang-Undang No.28 Tahun 2009 menyatakan bahwa Bea Balik Nama Kendaraan Bermotor adalah pajak atas penyerahan hak milik kendaraan bermotor sebagai akibat perjanjian dua belah pihak atau perbuatan sepihak atau keadaan yang terjadi karena jual beli, tukar menukar, hibah, warisan, atau pemasukan ke dalam badan usaha ${ }^{4}$. Penguasaan kendaraan bermotor yang melebihi dari jarak setahun atau duabelas bulan dapat dianggap sebagai penyerahan kendaraan bermotor, penguasaan kendaraan bermotor juga bisa dari luar negeri dan dipakai tetap diindonesia dengan pengecualian untuk dipergunakan diri sendiri atau orang pribadi, sebagai bahan untuk diperdagangkan. dengan penjabaran hal ini yang melatarbelakangi penulis untuk melakukan penelitian dengan judul “Analisis Efektifitas Penerimaan Pajak Dan Bea Balik Nama Kedaraan Bermotor Terhadap Pendapatan Asli Daerah Kabupaten Karawang Sebelum dan Sesudah diberlakukannya Surat Keputusan Gubernur Jawa Barat Nomor 973/147 Tahun $2018 "$

\footnotetext{
${ }^{3}$ Undang-Undang Republik Indonesia Nomor 28 Tahun 2009 Pasal 6 Pasal 12 Pajak Daerah Dan Retribusi daerah

${ }^{4}$ Abdul Halim, Perpajakan edisi 2 (Jakarta Selatan: Salemba Empat 2016), hlm. 506
} 


\section{Landasan Teori}

\section{Definisi Pajak}

Definisi pajak menurut Undang-Undang Nomor 16 tahun 2009

Tentang perubahan keempat atas Undang-Undang Nomor 6 tahun 1983 tentang Ketentuan Umum dan Tata cara perpajakan pada pasal 1 ayat 1 berbunyi pajak adalah kontribusi Wajib Pajak kepada negara yang terutang oleh orang pribadi atau badan yang bersifat memaksa berdasarkan Undang-Undang, dengan tidak mendapatkan imbalan secara langsung dan digunakan untuk diperlukan negara bagi sebesar-besarnya kemakmuran rakyat.

Definisi pajak yang dikemukakan oleh

Prof. Dr. Rochmat Soemitro, S.H.:

Pajak adalah iuran rakyat kepada kas negara berdasarkan undang-undang (yang dipaksakan) dengan tidak mendapat jasa timbal balik (kontraprestasi) yang langsung dapat ditunjukan dan yang digunakan untuk membayar pengeluaran umum. Definisi tersebut kemudian disempurnakan menjadi, Pajak adalah peralihan dari pihak rakyat kepada kas negara untuk membiayai pengeluaran rutin dan "surplus"-nya digunakan untuk publicsaving yang merupakan sumber utama untuk membiayai public investment.

\section{Definisi pajak yang dikemukakan oleh S. I. Djajadiningrat:}

Pajak sebagai suatu kewajiban menyerahkan sebagai dari kekayaan ke kas negara yang disebabkan suatu keadaan, kejadian, dan perbuatan yang memberikan kedudukan tertentu, tetapi bukan sebagai hukuman, menurut peraturan yang ditetapkan pemerintah serta dapat dipaksakan, tetapi tidak ada jasa timbal balik dari negara secara langsung untuk memelihara kesejahteraan secara umum.

Definisi pajak yang dikemukakan oleh Dr. N. J. Feldmann:

Pajak adalah presentasi yang dipaksakan sepihak oleh dan terutang kepada penguasa (menurut norma-norma yang ditetapkannya secara umum, tanpa adanya kontraprestasi, dan semata-mata digunakan untuk menutup pengeluaranpengeluaran umum. 


\section{Asas-asas Perpajakan}

Prinsip-prinsip ini masih digunakan sampai saat ini dalam sistem perpajakan modern. Tiga prinsip utama perpajakan menurut Adam Smith (1776) adalah:

\section{Effeciency}

Pemungutan pajak harus mudah dan murah dalam penagihannya, sehingga hasil pemungutan pajak lebih besar dari biaya pemungutannya.

2. Equity

Pemungutan pajak harus adil diantara satu wajib pajak dengan wajib pajak lainnya. Pajak dikenakan kepada wajib pajak harus sebanding dengan kemampuannya untuk membayar pihak tersebut dan manfaat yang diterimannya.

\section{Economic effect must be considered}

Pajak yang dikumpulkan dapat mempengaruhi kehidupan ekonomi wajib pajak. Hal ini harus dipertimbangkan ketika merumuskan kebijakan perpajakan. Pajak yang dikumpulkan jangan sampai membuat seseorang melarat atau mengganggukelancaran produksi perusahaan.

\section{Jenis Pajak}

Menurut Abdul Halim (2016:3) Terdapat berbagai jenis pajak yang dapat dikelompokan menjadi tiga, yaitu pengelompokan menurut golongan, menurut sifat, dan menurut lembaga pemungutnya.

1. Menurut Golongannya

Pajak dikelompokkan menjadi dua:

a. Pajak Langsung, pajak yang harus dipikul atau ditanggung sendiri oleh wajib pajak harus menjadi beban wajib pajak yang bersangkutan.

b. Pajak Tidak Langsung, pajak yang pada akhirnya dapat dibebankan atau dilimpahkan kepada orang lain atau pihak ketiga. Pajak tidak langsung terjadi jika terdapat suatu kejadian, peristiwa, atau perbuatan yang menyebabkan terutangnya pajak, misalnya terjadi penyerahan barang atau jasa.

\section{Menurut Sifat}

Pajak dapat dikelompokan menjadi dua. Berikut ini penjelasannya.

a. Pajak subjektif, pajak yang pengenaannya memperhatikan keadaan pribadi wajib pajak atau pengenaan pajak yang memperhatikan keadaan subjeknya. 
b. Pajak Objektif, pajak yang pengenaannya memperhatikan objeknya, baik berupa benda, keadaan, perbuatan, meupun peristiwa yang mengakibatkan keadaan pribadi subjek pajak (wajib pajak) dan tempat tinggal.

3. Menurut Lembaga Pemungutan

Pajak dikelompokan menjadi dua, berikut penjelasannya:

a. Pajak Negara (pajak Pusat), pajak yang dipungut oleh pemerintah pusat dan digunakan untuk membiayai rumah tangga negara pada umumnya.

Pajak Daerah, pajak yang dipungut oleh pemerintah daerah, baik daerah tingkat I (Pajak Provinsi) maupun daerah tingkat II (Pajak Kabupaten/ Kota), dan digunakan untuk membiayai rumah tangga

b. daerah masing-masing. Pajak Daerah diatur dalam Undang-Undang Nomor 28 Tahun 2009.

\section{Fungsi Pajak}

Menurut Abdul Halim (2016:4). Terdapat dua fungsi pajak, yaitu fungsi budgetair (sumber keuangan negara) dan fungsi regularend (pengatur)

1. Fungsi Budgetair(Sumber Keuangan Negara)

Pajak mempunyai fungsi budgetair, artinya pajak merupakan salah satu sumber penerimaan pemerintah untuk membiayai pengeluaran, baik rutin maupun pembangunan.

\section{Fungsi Regularend (Pengatur)}

Pajak mempunyai fungsi pengatur, artinya pajak sebagai alat untuk mengatur atau melaksanakan kebijakan pemerintah dalam bidang social dan ekonomi serta mencapai tujuan-tujuan tertentu diluar bidang keuangan.

\section{Syarat pemungutan pajak}

Menurut Mardiasmo (2016:4). Agar pemungutan pajak tidak menimbulkan hambatan atau perlawanan, maka pemungutan pajak harus memenuhi syarat sebagai berikut:

1. Pemungutan pajak harus adil (syarat keadilan)

Sesuai dengan tujuan hukum, yakni mencapai keadilan, undang-undang maupun pelaksanaan pemungutan pajak harus adil. Adil dalam perundang-undangan 
diantaranya mengenakan pajak secara umum dan merata, serta disesuaikan dengan kemampuan masing-masing. Sedang adil dalam pelaksanaannya yakni dengan memberikan hak wajib pajak untuk mengajukan keberatan, penundaan dalam pembayaran dan mengajukan banding kepada pengadilan pajak.

2. Pemungutan pajak harus berdasarkan undang-undang (syarat yuridis)Di indonesia, pajak diatur dalam UUD 1945 pasal 23 ayat 2. Hal ini memberikan jaminan hukum untuk menyatakan keadilan, baik bagi negara maupun warganya .

3. Tidak mengganggu perekonomian (syarat Ekonomis)

Pemungutan tidak boleh mengganggu kelancaran kegiatan produksi maupun perdagangan, sehingga tidak menimbulkan kelesuan perekonomian masyarakat.

4. Pemungutan pajak harus efesien (syarat finansiil)

Sesuai fungsi budgetair, biaya pemungutan pajak harus lebih rendah dari hasil pemungutannya.

5. Sistem pemungutan pajak harus sederhana

Sistem pemungutan yang sederhana akan memudahkan dan mendorong masyarakat dalam memenuhi kewajiban perpajakan. Syarat ini telah dipenuhi oleh Undangundang perpajakan yang baru.

\section{Pengelompokan Pajak}

Menurut mardiasmo (2016:7) pengelompokan pajak terbagi menjadi 3 yaitu :

1. Menurut golongannya

a. Pajak langsung, yaitu pajak yang harus dipikul sendiri oleh wajib pajak dan tidak dapat dibebankan atau dilimpahkan kepada orang lain

Contoh: pajak penghasilan

b. Pajak tidak langsung, yaitu pajak yang pada akhirnya dapat dibebankan atau dilimpahkan kepada orang lain.

Contoh: pajak pertambahan nilai

2. Menurut sifatnya

a. Pajak subjektif, yaitu pajak yang berpangkal atau berdasarkan pada

b. subjeknya, dalam arti memerhatikan keadaan dari wajib pajak.

Contoh: pajak penghasilan.

c. Pajak objektif, yaitu pajak yang berpangkal pada objeknya, tanpa memerhatikan keadaan diri Wajib Pajak 
Contoh: pajak pertambahan nilai dan pajak penjualan atas barang mewah.

\section{Tata cara pemungutan pajak}

Menurut Mardiasmo (2016:8). pemungutan pajak terbagi menjadi 3 Tata cara pemungtan pajak yaitu:

\section{Stelsel pajak}

Pemungutan pajak dapat dilakukan berdasarkan 3 stelsel:

a. Stelsel nyata (riel stelsel)

Pengenaan pajak didasarkan pada objek (penghasilan yang nyata), sehingga pemungutannya baru dapat dilakukan pada akhir tahun pajak, yakni setelah penghasilan yang sesungguhnya diketahui. Stelsel nyata mempunyai kelebihan atau kebaikan dan kekurangan. Kebaikan stelsel ini adalah pajak yang baru dapat dikenakan pada akhir periode (setelah penghasilan riil diketahui)

b. Stelsel anggapan (fictieve stelsel)

Pengenaan pajak didasarkan pada suatu tanggapan yang diatur oleh undangundang misalnya, penghasilan suatu tahun dianggap sama dengan tahun sebelumnya, sehingga pada awal tahun pajak sudah dapat ditetapkan besarnya pajak yang terutang untuk tahun pajak berjalan . kebaikan stelsel ini adalah pajak dapat dibayar selama tahun berjalan, tanpa harus menunggu akhir tahun. Sedangkan kelemahannya adalah pajak yang tidak berdasarkan pada keadaan yang sengguhnya.

c. Stelsel campuran

Stelsel ini merupakan kombinasi atara stelsel nyata dan stelsel anggapan. Pada awal tahun, besarnya pajak dihitung berdasarkan suatu anggapan, kemudian pada akhir tahun besarnya pajak disesuaikan dengan keadaan yang sebenarnya. Bila besarnya pajak menurut kenyataan lebih besar daripada pajak menurut anggapan,

maka Wajib Pajak harus menambah. Sebaiknya, jika lebih kecil kelebihannya dapat diminta kembali.

2. Asas Pemungutan Pajak

a. Asas domisili (asas tempat tinggal) 
Negara berhak mengenakan pajak atas seluruh penghasilan Wajib Pajak yang bertempat tinggal di wilayahnya, baik penghasilan yang berasal dari dalam maupun dari luar negeri. Asas ini berlaku untuk Wajib Pajak dalam negeri.

b. Asas sumber

Negara berhak mengenakan pajak atas penghasilan yang bersumber di wilayahnya tanpa memerhatikan tempat tinggal Wajib Pajak.

c. Asas kebangsaan

Pengenaan pajak dihubungkan dengan kebangsaan suatu negara.

3. Sistem Pemungutan Pajak

a. Official Assesment System

Adalah suatu sistem pemungutan yang memberi wewenang kepada pemerintah (fiskus untuk menentukan besarnya pajak yang terutang oleh Wajib Pajak)

b. Self Assessment System

Adalah suatu sistem pemungutan pajak yang memberi wewenang kepada Wajib Pajak untuk menentukan sendiri besarannya pajak yang terutang.

c. Withholding system

Adalah suatu sistem pemungutan pajak yang memberi wewenang kepada pihak ketiga (bukan fiskus dan bukan Wajib Pajak yang bersangkutan) untuk memotong atau memungut pajak yang terutang oleh Wajib Pajak.

\section{Tarif Pajak}

Menurut Abdul Halim (2016:505), Tarif pajak merupakan angka atau presentase yang digunakan untuk menghitung jumlah pajak atau jumlah pajak atau jumlah pajak yang terutang. Terdapat empat macam tarif pajak, yaitu:

\section{Tarif Tetap}

Tarif tetap, yaitu tarif dengan jumlah atau angka tetap berapa pun yang menjadi dasar pengenaan pajak sehingga besarnya pajak yang terutang tetap.

2. Tarif Sebanding (Proporsional)

Tarif sebanding (proporsional), yaitu tarif dengan presentase tetap berapa pun jumlah yang menjadi dasar pengenaan pajak, dan pajak yang harus dibayar selalu akan berubah secara proposional sesuai dengan jumlah yang akan dikenakan.

3. Tarif Progresif 
Tarif Progresif, yaitu tarif dengan presentase yang semakin meningkat (naik) apabila jumlah yang menjadi dasar pengenaan pajak meningkat.

4. Tarif Degresif (menurun)

Tarif Degresif (menurun), yaitu tarif dengan presentase yang semakin turun apabila jumlah yang menjadi dasar pengenaan pajak meningkat

\section{Pajak Kendaraan Bermotor (PKB)}

\section{Definisi Pajak Kendaraan Bermotor}

"Undang-Undang Nomor 28 Tahun 2009 menyatakan bahwa Pajak Kendaraan Bermotor adalah pajak atas kepemilikan dan/atau penguasaan kendaraan bermotor."

\section{Objek Pajak}

Menurut Abdul Halim (2016:503)

Objek Pajak Kendaraan Bermotor adalah kepemilikan dan/atau penguasaan kendaraan bermotor. Termasuk dalam pengertian kendaraan bermotor adalah kendaraan bermotor beroda berserta gandengannya yang dioperasikan disemua jenis jalan darat dan kendaraan bermotor yang dioperasikan di air dengan ukuran isi kotor GT 5 (lima Gross Tonnage) sampai dengan GT 7 (tujuh Gross Tonnage).

\section{Subjek Pajak}

Menurut Abdul Halim (2016:504):

Subjek Pajak Kendaraan Bermotor adalah Orang pribadi atau badan yang memiliki dan/atau menguasai Kendaraan Bermotor. Wajib Pajak Bermotor adalah orang probadi atau badan yang memiliki Kendaraan Bermotor. Dalam hal Wajib Pajak Badan, kewajiban perpajakannya diwakili oleh pengurus atau kuasa badan tersebut.

\section{Dasar Pengenaan Pajak}

Menurut Abdul Halim (2016:504), Dasar pengenaan Pajak Kendaraan Bermotor adalah hasil perkakalian dari dua unsur pokok:

1. Nilai Jual Kendaraan Bermotor; dan

2. Bobot yang mencerminkan secara relatif tingkat kerusakan jalan dan/atau pencemaran lingkungan akibat penggunaan Kendaraan Bermotor

\section{Tarif Pajak Kendaraan Bermotor}

Menurut Abdul Halim (2016:505), Tarif pajak kendaraan bermotor pribadi ditetapkan sebagai berikut: 
1. Untuk kepemilikan Kendaraan Bermotor pertama paling rendah sebesar 1 persen dan paling tinggi sebesar 2 persen.

2. Untuk kepemilikan Kendaraan Bermotor kedua dan seterusnya tarif dapat ditetapkan secara progresif paling rendah sebesar 2 persen dan paling tinggi sebesar 10 persen.

3. Untuk kendaraan bermotor angkutan umum, ambulans, pemadam kebakaran, sosial keagamaan, lembaga sosial dan keagamaan, pemerintah /TNI/POLRI, Pemerintah Daerah, dan kendaraan lain.

4. Untuk kendaraan bermotor alat-alat berat dan alat-alat besar ditetapkan paling rendah sebesar 0,1 persen dan paling tinggi sebesar 0,2 persen

\section{Perhitungan Pajak Kendaraan Bermotor}

Menurut Abdul Halim (2016:505), Besaran pokok pajak kendaraan bermotor yang terutang dihitung dengan cara mengalikan tarif dengan dasar pengenaan pajak.

Tarif Pajak x Dasar Pengenaan Pajak

\section{Bea Balik Nama Kendaraan Bermotor}

\section{Definisi Bea Balik Nama Kendaraan Bermotor}

Undang-Undang Nomor 28 Tahun 2009 menyatakan bahwa Bea Balik Nama kendaraan Bermotor adalah pajak atas penyerahan hak milik kendaraan bermotor sebagai akibat perjanjian kedua pihak atau perbuatan sepihak atau keadaan yang terjadi karena jual beli, tukar menukar, hibah, warisan, atau pemasukan kedalam badan usaha.

\section{Objek Pajak}

Menurut Abdul halim (2016:506), Objek pajak Bea Balik Nama Kendaraan Bermotor adalah:

penyerahan kepemilikan kendaraan bermotor. Termasuk dalam pengertian kendaraan bermotor adalah kendaraan bermotor beroda berserta gandengannya yang dioperasikan disemua jenis jalan darat dan kendaraan bermotor yang dioperasikan di air dengan ukuran isi kotor GT 5 (lima Gross Tonnage) sampai dengan GT 7 (tujuh Gross Tonnage).

\section{Penyerahan Kendaraan Bermotor}


Menurut Abdul Halim (2016:506)beberapa hal terkait penyerahan kendaraan bermotor ada empat yaitu:

1. Penguasaan Kendaraan bermotor melebihi dua belas bulan dapat dianggap sebagai penyerahan.

2. Penguasaan Kendaraan Bermotor tidak termasuk penguasaan Kendaraan Bermotor karena perjanjian sewa beli.

3. Termasuk penyerahan Kendaraan Bermotor adalah pemasukan Kendaraan Bermotor dari luar negeri untuk dipakai secara tetap di Indonesia.

\section{Subjek Pajak}

Menurut Abdul Halim (2016:507), Subjek Pajak Bea Balik Nama Kendaraan Bermotor adalah:

"orang pribadi atau Badan yang dapat menerima penyerahan Kendaraan Bermotor. Wajib Pajak Bea Balik Nama Kendaraan Bermotor adalah orang pribadi atau Badan yang menerima penyerahan Kendaraan Bermotor".

\section{Dasar Pengenaan Pajak dan Tarif}

Menurut Abdul Halim (2016:508), Dasar pengenaan Bea Balik Nama Kendaraan Bermotor adalah Nilai Jual Kendaraan Bermotor. Tarif Bea Balik Nama Kendaraan Bermotor ditetapkan paling tinggi masing-masing sebagai berikut:

1. Penyerahan pertama sebesar 20 persen; dan

2. Penyerahan kedua dan seterusnya sebesar 1 persen.

Khusus untuk Kendaraan Bermotor alat-alat berat dan alat-alat besar yang tidak menggunakan jalan umum tarif pajak ditetapkan sebagai berikut:

1. Penyerahan pertama sebesar 0,75 persen; dan

2. Penyerahan kedua dan seterusnya sebesar 0,075 persen.

\section{Perhitungan Bea Balik Nama Kendaraan Bermotor}

Menurut Abdul Halim (2016:508), Tarif Bea Balik Nama Kendaraan Bermotor ditetapkan dengan peraturan daerah. Besaran pokok pajak Bea Balik Nama Kendaraan Bermotor yang terutang dihitung dengan cara mengalikan tarif dengan dasar pengenaan pajak.

\section{Efektivitas (effectivity)}


Kata efektivitas berasal dari bagasa Inggris yaitu effective yang berarti berhasil atau sesuatu yang dilakukan berhasil dengan baik. Kamus ilmiah populer mendefinisikan efektivitas sebagai ketepatan penggunaan, hasil guna atau menunjang tujuan. Efektivitas menggambarkan kemampuan Pemerintah Daerah dalam merealisasikan Pajak Daerah yang direncanakan dibandingkan dengan target yang ditetapkan berdasarkan potensi riil daerah. Efektivitas ini dapat dihitung dengan rumus:

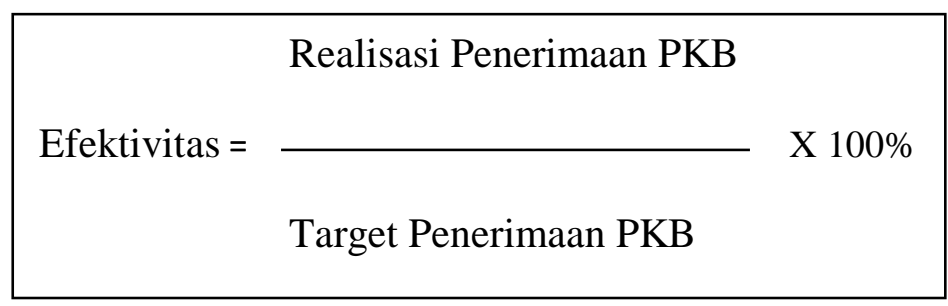

(Abdul halim, $2004:$ 135)

\section{Kerangka berpikir}

Masing-masing daerah memiliki berbagai macam cara untuk meningkatkan pendapatan daerahnya, hal tersebut juga terjadi didaerah Kabupaten Karawang, dimana salah satu penghasilan pendapatan asli daerah yaitu salah satunya bersumber dari pajak, pada bagian pajak menerbitkan tentang peraturan perundang-undangan Nomor 28 Tahun 2009 menyatakan bahwa Pajak Kendaraan Bermotor adalah pajak atas kepemilikan dan/atau penguasaan kendaraan bermotor.

Pada penelitian ini menggunakan kerangka berpikir yang telah disimpulkan pada teori yang telah diuraikan pada deskriptif teori, penulis menganalisis yang berjudul Analisis Efektivitas Penerimaan Pajak dan Bea Balik Nama Pajak Kendaraan Bermotor Terhadap Penerimaan Asli Daerah Kabupaten Karawang yang ditujukan untuk menganalisis bagaimana besarnya efektivitas penerimaan pajak kendaraan bermotor yang terrealisasi pada 5 tahun terakhir, yaitu pada tahun 2014 sampai dengan 2018, Menganalisis besaran Bea Balik Nama Kendaraan Bermotor yang terrealisasi pada 5 tahun terakhir, yaitu tahun 2014 sampai dengan tahun 2018, menganalisis apa saja kebijakan yang diberlakukan dalam meningkatkan pendapatan daerah di Kabupaten Karawang, dan besaran tarif yang diberlakukan pada Bea Balik Nama Kendaraan Bermotor.

\section{Gambar 2.4}




\section{Kerangka berpikir}

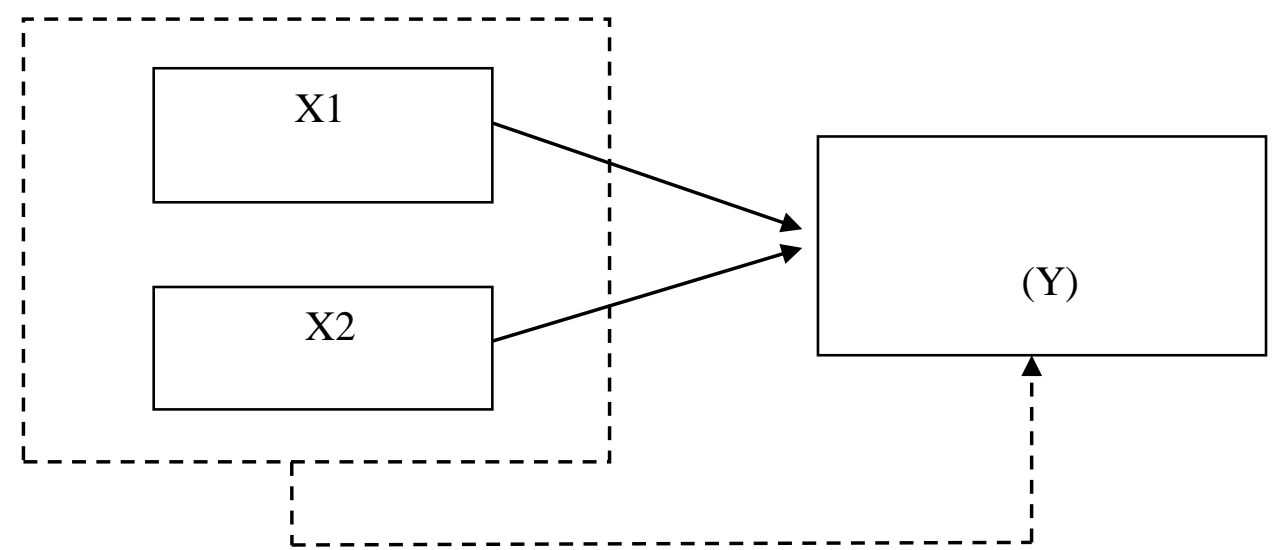

Keterangan :

1. Variabel independen dalam penelitian ini yaitu Efektivitas Penerimaan Pajak Kendaraan Bermotor sebagai (X1) dan Bea Balik Nama Kendaraan Bermotor sebagai (X2).

2. Variabel dependen dalam penelitian ini yaitu Pendapatan Daerah Kabupaten Karawang sebagai variabel terikat (Y)

\section{Hipotesis Penelitian}

Berdasarkan rumusan masalah, tujuan, tinjauan pustaka dan kerangka berpikir diatas, maka peneliti menyimpulkan hipotesis penelitian sebagai berikut:

\section{Pengaruh Efektivitas Penerimaan Pajak Kendaraan Bermotor terhadap Pendapatan Asli Daerah Kabupaten Karawang}

$\mathrm{Ho}_{1}$ : Tidak terdapat pengaruh antara efektivitas penerimaan pajak kendaraan bermotor terhadap Pendapatan Asli Daerah di Kabupaten Karawang Sebelum dan Sesudah Berlakunya Surat Keputusan Gubernur Jawa Barat pada tahun $2016-2018$

$H a_{1}$ : Terdapat Pengaruh antara Efektivitas Penerimaan Pajak Kendaraan Bermotor terhadap Pendapatan Asli Daerah di Kabupaten Karawang Sebelum dan Sesudah Berlakunya Surat Keputusan Gubernur Jawa Barat pada tahun 20162018 
2. Pengaruh Bea Balik Nama Kendaraan Bermotor terhadap Pendapatan Asli Daerah Kabupaten Karawang

$\mathrm{Ho}_{2}$ : Tidak terdapat pengaruh antara Bea Balik Nama Kendaraan Bermotor tehadap Pendapatan Asli Daerah Kabupaten Karawang Sebelum dan Sesudah Berlakunya Surat Keputusan Gubernur Jawa Barat pada tahun 2016-2018

$\mathrm{Ha}_{2}$ : Terdapat pengaruh antara Bea Balik Nama Kendaraan Bermotor tehadap Pendapatan Asli Daerah Kabupaten KarawangSebelum dan Sesudah Berlakunya Surat keputusan Gubernur Jawa Barat pada tahun 2016-2018

\section{Pengaruh Efektivitas Penerimaan Pajak dan Bea Balik Nama Kendaraan} Bermotor terhadap Pendapatan Asli Daerah

$\mathrm{Ho}_{3}$ : Tidak terdapat pengaruh antara efektivitas penerimaan pajak dengan Bea Balik

Nama Kendaraan Bermotor Terhadap Pendapatan Asli Daerah Kabupaten Karawang Sebelum dan Sesudah Berlakunya Surat keputusan Gubernur Jawa Barat pada tahun 2016-2018

$\mathrm{Ha}_{3}$ : Terdapat pengaruh antara efektivitas penerimaan pajak dengan Bea Balik Nama Kendaraan Bermotor terhadap Pendapatan Asli Daerah Kabupaten Karawang Sebelum dan Sesudah Berlakunya Surat keputusan Gubernur Jawa Barat pada tahun 2016-2018 


\section{Metode Penelitian}

Dalam penelitian ini peneliti menggunakan metode penelitian deskriptif.Menurut Sumadi Suryabrata (2014:75),Penggunaanpenelitian deskriptif adalah untuk membuat pencandraan secara sistematis, faktual, dan akurat mengenai fakta-fakta dan sifat-sifat populasi atau daerah tertentu

\section{Sumber Data}

Data dalam penelitian ini bersifat time series, yaitu data yang menggambarkan perkembangan dari waktu ke waktu, pada penelitian ini jenis data yang digunakan yaitu data sekunder, data yang tidak didapat secara langsung dari objek penelitian namun melalui media informasi yang berupa data tahunan yang diberikan oleh pihak SAMSAT Kabupaten Karawang dari data tahun 2014 sampai dengan 2018

\section{Instrumen Penelitian}

Pada penelitian ini membutuhkan beberapa instrumen untuk mendapatkan data yang valid. Sesuai dengan penelitian ini yaitu bersifat penelitian kualitatif yang merupakan instrumen utama yang digunakan dalam penelitian ini memahami metode penelitian ini sebagai acuan dalam pengetahuan pengujian kevalidan data dalam efektivitas penelitian pajak kendaraan bermotor setelah dan sebelum adanya kebebasan denda pada periode 1 Juli sampai 31 Agustus

Adanya penelitian ini melakukan pengamatan dengan cara terjun langsung ke lapangan yaitu ke SAMSAT Kabupaten Karawang, untuk menganalisis perkembangan efektivitas penerimaan pajak yang memerlukan data dari informasi SAMSAT Kabupaten Karawang yang merupakan salah satu sumber Pendapatan Asli Daerah Kabupaten Karawang.

\section{Teknik Pengumpulan Data}

Dalam penelitian ini, peneliti melakukan pengumpulan data dengan menggunakan cara:

1. Penelitian lapangan, yaitu data yang diperoleh dari SAMSAT Kabupaten Karawang yang dipergunakan untuk penelitian ini. 
2. Dari tinjauan pustaka, dari berbagai macam buku yang dapat ditelaah dan dipelajari, membaca yang berhubungan dengan judul skripsi yaitu mengenai perpajakan daerah

3. Wawancara, adalah pengumpulan data dengan mengajukan pertanyaan langsung oleh pewawancara kepada pihak yang diwawancara, dalam penelitian ini pihak yang diwawancarai adalah pihak SAMSAT Kabupaten Karawang.

\section{Teknik Analisis Data}

Teknik analisis data dalam penelitian ini, data diperoleh dengan menggunakan cara wawancara dan dokumentasi. Teknik analisis data yang digunakan adalah teknik analisis efektivitas. Abdul Halim (2002: 129) mengatakan bahwa teknik analisis yang dipergunakan untuk mengukur efektivitas adalah Rasio Efektivitas. Rasio ini menggambarkan kemampuan Pemerintah Daerah baik dalam merealisasi Pajak Kendaraan Bermotor maupun Bea Balik Nama Kendaraan Bermotor.

Rumus yang digunakan untuk mengukur efektivitas adalah sebagai berikut:

\begin{tabular}{|cc|}
\hline Change Price Index $=$ & Realisasi penerimaan PKB \\
Target penerimaan PKB & \\
\hline
\end{tabular}

Berdasarkan keputusan Mentri Dalam Negeri Nomor : 690.900-327 Tahun 1994 bahwa kriteria penilaian dan kinerja keuangan dapat diketahui efektif atau tidak dengan memenuhi kriteria sebagai berikut :

\section{Klasifikasi Tingkat Efektivitas}

\begin{tabular}{|l|l|}
\hline Presentase & Tingkat Efektivitas \\
\hline$\geq 100 \%$ & Sangat efektif \\
\hline $90 \%-100 \%$ & Efektif \\
\hline $80 \%-90 \%$ & Cukup efektif \\
\hline $60 \%-80 \%$ & Kurang Efektif \\
\hline
\end{tabular}




$$
\leq 60 \%
$$

Tidak efektif

\section{ANALISIS DATA}

\section{Deskripsi Data}

Dalam menentukan efektivitas adalah dengan menggunakan target dan realisasi penerimaan pajak kendaraan bermotor dan Bea Balik nama kendaraan Bermotor

1. Target Penerimaan pajak kendaraan bermotor dan Bea Balik Nama Kendaraan Bermotor.

a. Data Penerimaan Pajak Kendaraan Bermotor Kabupaten Karawang yang diperoleh dengan jangka 5 tahun terakhir yaitu sejak tahun 2014 sampai dengan 2018. Data tersebut ada pada Tabel V.1

\section{Target penerimaan pajak kendaraan bermotor pada tahun 2014 sampai dengan} 2018.

\begin{tabular}{|l|l|}
\hline Tahun & Target PKB \\
\hline 2014 & 172.433 .230 .000 \\
\hline 2015 & 204.333 .000 .000 \\
\hline 2016 & 240.864 .000 .000 \\
\hline 2017 & 251.390 .000 .000 \\
\hline 2018 & 309.415 .000 .000 \\
\hline
\end{tabular}

b. Data Bea Balik Nama Kendaraan Bermotor Kabupaten Karawang yang diperoleh dengan jangka 5 tahun terakhir yaitu sejak tahun 2014 sampai dengan 2018. 
Target Bea Balik Nama Kendaraan Bermotor Kabupaten Karawang pada tahun 2014 sampai dengan 2018.

\begin{tabular}{|c|c|}
\hline Tahun & Target Bea Balik Nama Kendaraan ke-II \\
\hline 2014 & 3.943 .769 .000 \\
\hline 2015 & 2.924 .700 .000 \\
\hline 2016 & 2.973 .000 .000 \\
\hline 2017 & 4.356 .000 .000 \\
\hline 2018 & 3.753 .000 .000 \\
\hline
\end{tabular}

Pada penelitian ini, data yang didapatkan pada kantor Samsat Kabupaten Karawang sesuai dengan pemberlakuan surat edaran gubernur jawa barat mengenai pemberlakuan program pembebasan tahun 2018 atas surat keputusan Gubernur Nomor : 973/154 tentang pemberian kebebasan pokok dan Sanksi Administrasi berupa Bea Balik Nama Kendaraan Bermotor (BBNKB) atas penyerahan kedua dan seterusnya, serta pembebasan sanksi Administrasi berupa denda pakan kendaraan bermotor (PKB) yang berlaku pada tanggal 01 Juli 2018 sampai dengan 31 Agustus 2018. Sehingga dalam penghitungan efektifitas Penerimaan Pajak Kendaraan Bermotor dan Bea Balik Nama Kendaraan Bermotor menggunakan perhitungan data setiap tahunnya sebelum dan sesudah adanya peraturan surat keputusan gubernur jawa barat sebesar Rp. 3.753.000.000

2. Realisasi Pajak Kendaran Bermotor dan Bea Balik Nama Kendaraan Bermotor ke 2

a. Data realisasi penerimaan pajak kendaraan bermotor yang diperoleh dalam jangka waktu lima tahun terakhir, yaitu dari tahun 2014 sampai dengan 2018 dalam angka tahunan. Data tersebut dapat dilihat pada tabel 4.3.

\section{Realisasi penerimaan pajak kendaraan bermotor pada tahun 2014 sampai dengan tahun 2018.}

\begin{tabular}{|c|c|}
\hline Tahun & Realisasi Penerimaan Pajak Kendaraan Bermotor \\
\hline
\end{tabular}




\begin{tabular}{|c|c|}
\hline 2014 & 189.988 .879 .300 \\
\hline 2015 & 211.659 .962 .300 \\
\hline 2016 & 250.283 .704 .900 \\
\hline 2017 & 269.712 .673 .400 \\
\hline 2018 & 324.940 .184 .400 \\
\hline
\end{tabular}

b. Realisasi Bea Balik Nama kendaraan Bermotor pada Kabupaten Karawang yang diperoleh dalam jangka lima tahun terakhir, yaitu dari tahun 2014 sampai dengan 2018 dalam angka tahunan.

\section{Realisasi Bea Balik Nama Kendaraan Bermotor pada tahun 2014 sampai dengan 2018.}

\begin{tabular}{|l|l|}
\hline Tahun & Realisasi Bea Balik Nama Kendaraan Bermotor Ke-II \\
\hline 2014 & 2.938 .948 .500 \\
\hline 2015 & 2.847 .958 .600 \\
\hline 2016 & 3.231 .876 .000 \\
\hline 2017 & 4.715 .372 .100 \\
\hline 2018 & 4.183 .794 .000 \\
\hline
\end{tabular}

\section{Analisis Data}

\section{Menghitung Efektivitas}

Dalam melakukan penganalisaan data, peneliti terlebih dahulu menghitung efektivitas Penerimaan Pajak Kendaraan Bermotor dan Bea Balik Nama Kendaraan Bermotor pada lima tahun terakhir sebelim dan sesudah pemberlakuan surat keputusan Gubernur Jawa Barat Nomor 973/154 tahun 2018 dengan metode Change Perfomance Index (CPI): 
Thomas Nadeak, Eva Sunasti Vol 4 No 1 ISSN : 2541-6995

E ISSN : 2580-5517

$\mathrm{CPI}=\frac{\text { Realisasi }}{\text { Target }} \times 100 \%$

Contoh perhitungan :

Efektivitas $2014=\frac{\text { realisasi penerimaan }(\text { PKB )Tahun } 2014}{\text { Target Penerimaan (PKB)Tahun } 2014} \times 100 \%$

$$
\begin{aligned}
& =\frac{189.988 .879 .300}{172.433 .230 .000} \times 100 \% \\
& =11.0181128 / 110,18 \%
\end{aligned}
$$

Efektivitas 2014 $=\frac{\text { realisasi BBNKB Tahun } 2014}{\text { Target BBNKB Tahun } 2014} \times 100 \%$

$$
\begin{aligned}
& =\frac{2.938 .948 .500}{3.943 .769 .000} \times 100 \% \\
& =0.7452121 / 74,52 \%
\end{aligned}
$$

Efektivitas $2015=\frac{\text { realisasi penerimaan }(\text { PKB }) \text { Tahun } 2015}{\text { Target Penerimaan }(P K B) \text { Tahun } 2015} \times 100 \%$

$$
\begin{aligned}
& =\frac{211.659 .962 .300}{204.333 .000 .000} \times 100 \% \\
& =1.0358579 / 103,59
\end{aligned}
$$

Efektivitas $2015=\frac{\text { realisasi BBNKB Tahun } 2015}{\text { Target } B \text { BNKB Tahun } 2015} \times 100 \%$

$$
\begin{aligned}
& =\frac{2.847 .958 .600}{2.924 .700 .000} \times 100 \% \\
& =0,9737609 / 97,38
\end{aligned}
$$

Efektivitas $2016=\frac{\text { realisasi penerimaan (PKB)Tahun } 2016}{\text { Target Penerimaan }(\text { PKB)Tahun } 2016} \times 100 \%$

$$
=\frac{250.283 .704 .900}{240.864 .000 .000} \times 100 \%
$$


Thomas Nadeak, Eva Sunasti Vol 4 No 1 ISSN : 2541-6995

E ISSN : 2580-5517

$$
=1.0391079
$$

Efektivitas $2016=\frac{\text { realisasi } B \text { BNKB Tahun } 2016}{\text { Target } B \text { BNKB Tahun } 2016} \times 100 \%$

$$
\begin{aligned}
& =\frac{3.231 .876 .000}{2.973 .000 .000} \times 100 \% \\
& =1.0870756
\end{aligned}
$$

Efektivitas $2017=\frac{\text { realisasi penerimaan }(\text { PKB }) \text { Tahun } 2017}{\text { Target Penerimaan }(\text { PKB }) \text { Tahun } 2017} \times 100 \%$

$$
\begin{aligned}
& =\frac{269.712 .673 .400}{251.398 .000 .000} \times 100 \% \\
& =1.0728513
\end{aligned}
$$

Efektivitas $2017=\frac{\text { realisasi BBNKB Tahun } 2017}{\text { Target BBNKB Tahun } 2017} \times 100 \%$

$$
\begin{gathered}
=\frac{4.715 .372 .100}{4.356 .000 .000} \times 100 \% \\
=1.0825004
\end{gathered}
$$

Efektivitas $2018=\frac{\text { realisasi penerimaan }(\text { PKB }) \text { Tahun } 2019}{\text { Target Penerimaan }(\text { PKB }) \text { Tahun } 2018} \times 100 \%$

$$
\begin{aligned}
& =\frac{324.940 .184 .400}{309.415 .000 .000} \times 100 \% \\
& =1.0501759
\end{aligned}
$$

Efektivitas $2018=\frac{\text { realisasi BBNKB Tahun } 2018}{\text { Target BBNKB Tahun } 2018} \times 100 \%$

$$
\begin{aligned}
& =\frac{4.183 .794 .000}{3.753 .000 .000} \times 100 \% \\
& =1.1147865
\end{aligned}
$$


Efektivitas penerimaan pajak kendaraan bermotor pada tahun 2014 sampai dengan 2018.

\begin{tabular}{|c|c|}
\hline Tahun & $\begin{array}{c}\text { Efektifitas penerimaan Pajak Kendaraan } \\
\text { Bermotor }\end{array}$ \\
\hline 2014 & 110,18 \\
\hline 2015 & 103,59 \\
\hline 2016 & 103,91 \\
\hline 2017 & 107,29 \\
\hline 2018 & 105,02 \\
\hline Rata- rata & 105,99 \\
\hline (Mean) & \\
\hline
\end{tabular}

Tabel 4.6

Efektivitas Bea Balik Nama Kendaraan Bermotor di Kabupaten Karawang pada tahun 2014 sampai dengan 2018.

\begin{tabular}{|c|c|}
\hline Tahun & Efektivitas Bea Balik Nama Kendaraan Bermotor \\
\hline 2014 & 74,52 \\
\hline 2015 & 97,38 \\
\hline 2016 & 108,71 \\
\hline 2017 & 92,94 \\
\hline
\end{tabular}




\begin{tabular}{|c|c|}
\hline 2018 & 112,90 \\
\hline $\begin{array}{c}\text { Rata-rata } \\
\text { (mean) }\end{array}$ & 97,29 \\
\hline
\end{tabular}

Setelah melakukan perhitungan efektifitas yang telah dihitung pada tabel 4.5 dan tabel kemudian dilakukannya penentuan kriteria efiktifitas seperti ketentuan pada tabel 3.

\section{Uji t atau Uji beda rata-rata}

Setelah mengetahui berapa nilai efektivitas yang ada maka peneliti akan melakukan perhitungan Uji $\mathrm{t}$ atau uji beda rata-rata yang bertujuan untuk mengetahui bagaimana ada atau tidaknya perbedaan yang signifikan terhadap efektivitas penerimaan pajak kendaraan bermotor dan Bea Balik nama kendaraan Bermotor sebelum dan sesudah diberlakukannya surat keputusan Gubernur Nomor 973/154 tahun 2018.

\section{Perumusan Hipotesa}

Ho : tidak ada perbedaan yang signifikan terhadap efektivitas penerimaan pajak kendaraan bermotor dan Bea Balik Nama Kendaraan bermotor sebelum dan sesudah berlakunya Surat Keputusan Gubernur Jawa Barat Nomor 973/154 tahun 2018

(Ho : $\mu_{1}=\mu_{2}$ ).

Ha : Ada perbedaan yang signifikan terhadap efektivitas penerimaan pajak kendaraan bermotor dan Bea Balik Nama Kendaraan bermotor sebelum dan sesudah berlakunya Surat Keputusan Gubernur Jawa Barat Nomor 973/154 Tahun 2018

$\left(\mathrm{Ha}: \mu_{1} \neq \mu_{2}\right)$

$\mu_{1}$ : Tingkat efektivitas sebelum berlakunya Surat Keputusa Gubernur Jawa Barat Nomor 973/154 Tahun 2018

$\mu_{2}$ : Tingkat efektivitas sesudah berlakunya Surat Keputusan Gubernur Jawa Barat Nomor 973/154 Tahun 2018 
Tanda $\neq$ pada Ha menunjukan uji dua arah.

\section{Menentukan taraf nyata dan derajat bebas $(d f)$}

Taraf nyata yang digunakan dalam ilmu ekonomi sebesar 0,5 artinya batasan kesalahan atau penyimpangan yang masih dapat diterima dari hasil penelitian ini sebesar 0,5 . Untuk menentukan derajat bebas $(d f)$ dengan menggunakan rumus $\mathrm{df}=$ $\mathrm{n}-1=5-1=4$

\section{Uji statistik t}

Uji statistik atau uji beda rata-rata yaitu dengan menghitung jumlah selisih efektivitas sebelum dan sesudah pemberlakuan Surat Keputusan Gubernur Jawa Barat Nomor 973/154 tahun 2018 (d) dan jumlah kuadrat efektivitas sebelum dan sesudah pemberlakuan Surat Keputusan Gubernur Jawa Barat Nomor 973/154 tahun $2018\left(d^{2}\right)$. Dengan menggunakan program Microsoft exel hasilnya dapat dilihat pada Tabel 4.7

Jumlah selisih efektivitas penerimaan Pajak Kendaraan Bermotor (d) dan jumlah kuadrat efektivitas penerimaan Pajak Kendaraan Bermotor $\left(d^{2}\right)$.

\begin{tabular}{|c|c|c|c|}
\hline $\begin{array}{l}\text { Efektivitas } \\
\text { Target }\end{array}$ & $\begin{array}{l}\text { Efektivitas } \\
\text { Realisasi }\end{array}$ & $d$ & $d^{2}$ \\
\hline 172.433 .230 .000 & 189.988 .879 .300 & 10.18 & 103.63 \\
\hline 204.333 .000 .000 & 211.659 .962 .300 & 03.59 & 12.89 \\
\hline 240.864 .000 .000 & 250.283 .704 .900 & 03.91 & 15.29 \\
\hline 251.390 .000 .000 & 269.712 .673 .400 & 07.29 & 53.14 \\
\hline 309.415 .000 .000 & 324.940 .184 .400 & 05.02 & 25.20 \\
\hline \multicolumn{2}{|l|}{ Jumlah } & 29.99 & 210.15 \\
\hline$s d=\sqrt{\frac{\sum_{d^{2}}-\frac{(\Sigma}{n-1}}{n}}$ & 210.15 & $\frac{\frac{(29.99)^{2}}{5}}{1}$ & \\
\hline
\end{tabular}


Thomas Nadeak, Eva Sunasti

Vol 4 No 1

ISSN : 2541-6995

E ISSN : 2580-5517

$t=\frac{\bar{d}-\mu_{1}}{s d / \sqrt{n}}=\frac{\left(\frac{29.99}{5}\right)-0}{5.13 / \sqrt{5}}=2.6$

Jumlah selisih efektivitas Bea Balik Nama Kendaraan Bermotor II (d) dan jumlah kuadrat efektifitas Bea Balik Nama Kendaraan Bermotor II $\left(d^{2}\right)$

\begin{tabular}{|c|c|c|c|}
\hline Efektivitas & Efektivitas & \\
target & Realisasi & $d$ & $d^{2}$ \\
\hline 3.943 .769 .000 & 2.938 .948 .500 & $-25,48$ & 649,23 \\
\hline 2.924 .700 .000 & 2.847 .958 .600 & 3,59 & 12,88 \\
\hline 2.973 .000 .000 & 3.231 .876 .000 & 8,71 & 75,86 \\
\hline 4.356 .000 .000 & 4.715 .372 .100 & 8,25 & 68,06 \\
\hline 3.753 .000 .000 & 4.183 .794 .000 & 11,47 & 13,15 \\
\hline Jumlah & & & \\
\hline
\end{tabular}

\section{Menentukan daerah keputusan}

Nilai kritis atau t tabel dari uji dua arah dengan taraf nyata yaitu 0,5 dengan derajat bebas $(d f)=4$ adalah 2.132

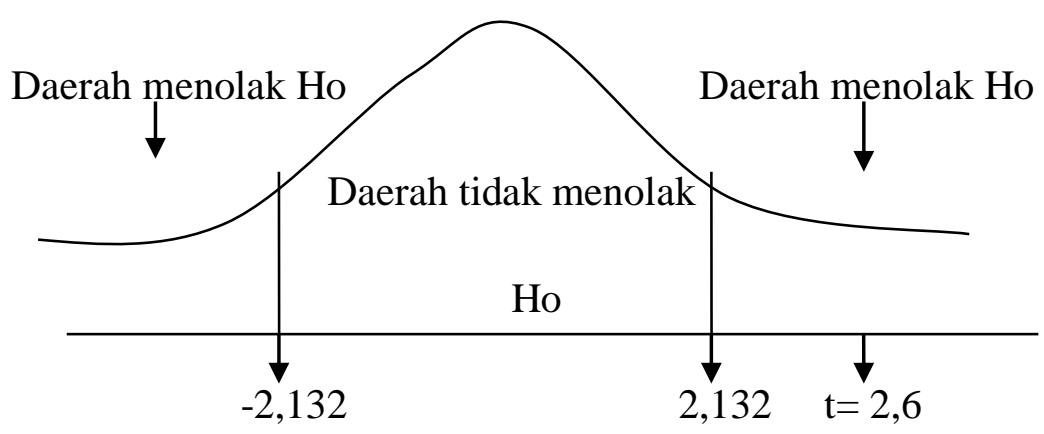




\section{Pembahasan}

Data yang diteliti pada penelitian ini sejak tahun 2014 sampai dengan 2018, pada tahun 2014 belum ada pemberlakuan surat keputusan Gubernur Jawa Barat mengenai pemberian pembebasan pokok dan sanksi administratif berupa denda Bea Balik Nama Kendaraan Bermotor (BBNKB) atas penyerahan kepemilikan kedua dan seterusnya, serta pembebasan sanksi administratif berupa denda pajak kendaraan bermotor, sebelum adanya pembebasan hal tersebut pada tahun 2014 Penerimaan Pajak Kendaraan Bermotor memperoleh penerimaan $10.18 \%$ dari jumlah target yang ingin dicapai, sementara pada penerimaan Bea Balik Nama Kendaraan Bermotor terdapat penerimaan sebesar -25,48 kemudian pada tahun 2015 mengalami peningkatan target penerimaan yaitu dari target sebelumnya Rp.204.333.000.000 dari tahun sebelumnya yang memiliki target Rp.172.433.230.000 pada tahun 2016 penerimaan pajak kendaraan bermotor mulai melakukan pemberlakuan surat keputusan gubernur nomor 973/499 yang berlaku pada tanggal 17 Oktober 2016 sampai dengan tanggal 24 Desember 2016 mengalami penerimaan sebesar 250.283.704.900 dan penerimaan bea balik nama kendaraan bermotor mengalami penerimaan sebesar 3.231.876.000. Pada tahun 2017 penerimaan pajak kendaraan bermotor sebesar 269.712.673.400 sedangkan untuk penerimaan bea balik nama kendaraan bermotor sebesar 4.715.372.100. Pada tahun 2018 dimana pemberlakuan pembebasan pokok dan sanksi administrasif berupa denda ea balik nama kendaraan bermotor (BBNKB) atas penyerahan kepemilikan kedua dan seterusnya. Hal tersebut mempengaruhi target dan realisasi penerimaan yang diterima sebesar 324.940.184.400 dari target yang ditentukan yaitu sebesar 309.415.000.000 dan untuk bea balik nama kendaraan bermotor sebesar 4.183.794.000.

\section{Kesimpulan}

Berdasarkan hasil penelitian yang telah diuraikan, peneliti mengambil beberapa kesimpulan sebagai berikut: 
1. Realisasi penerimaan pajak kendaraan bermotor berdasarkan target yang telah ditentukan oleh pemerintahan Kabupaten Karawang pada tahun 2014 sampai dengan 2018 nilai rata-rata yang diterima terealisasi sangat efektif yakni 105,99\%, dengan adanya pemberlakuan pembebasan denda pada surat keputusan gubernur nomor 973/154, Yakni realisasi penerimaan mencapai 105,02\%

2. Bea balik nama kendaraan bermotor dengan adanya pemberlakuan pembebasan bea balik nama kendaraan bermotor pada tahun 2014 sampai dengan 2018 rata-rata yang diterima berkurang dari jumlah target yang telah ditentukan dimana hanya mencapai presentase hingga 97,29\% dari target yang di tentukan bisa dikatakan efektif. Pada tahun 2018 saat pemberlakuan surat keputusan gubernur nomor 973/154, yakni terealisasi sebesar $112,90 \%$

3. Efektivitas penerimaan pajak kendaraan bermotor dan bea balik nama kendaraan bermotor terhadap pendapatan asli daerah yakni sangat efektif, dimana penetapan penerapan adanya pemungutan pajak kendaraan bermotor dapat meningkatkan pendapatan daerah yang terbanyak dari pendapatan pajak daerah yg lainnya.

\section{Daftar Pustaka}

Boediono,B.2011. Pelayanan Prima Perpajakan .Jakarta : Rineka Cipt

Darmawan.2013 . Metode Penelitian Kuantitatif . Bandung : Remaja Rosdakarya

Halim,Abdul. Icuk Rangga Bawono Dara, Amin . Perpajakan Edisi 2 Jakarta Selatan : Salemba Empat 2016

Mardiasmo,(2008) Perpajakan Edisi Revisi 2008 Yokyakarta : Andi Publisher

Mardiasmo,( 2013 ) Perpajakan Edisi Revisi 2013, Yokyakarta : CV. Andi Offset

Mardiasmo,(2016) Perpajakan Edisi terbaru 2016 Yokyakarta : CV.Andi Offset 
Resmi, Siti (2016) Perpajakan Teori dan Kasus Edisi 9 Buku 1 Jakarta Selatan 12610 : Salemba Empat.

Ridwan,(2011) Hukum Administrasi Negara, edisi Revisi Jakarta : Rajawali Pers

Suhartono, Irawan 2010. Metode Penelitian Sosial Suatu Teknik Penelitian bidang kesejahteraan Sosial dan Ilmu Sosial lainnya. Bandung : PT.Remaja Rosdakarya

Supardi.(2013).Aplikasi Statistika dalam penelitian konsep Statistika yang lebih komprehenship.Jakarta : Change Publication

Sugiono .2015 Metode Penelitian Pendidikan ( Pendekatan Kuantitatif,Kualitatif dan R\&D ) Penerbit CV.Alfabeta Bandung

Undang-Undang Nomor 28 tahun 2009 pasal 1 angka 12, Pajak Daerah dan Retribusi Daerah www.pajak.go.id

https://bapeda.jabarprov.go.id/2018/6/6 